\title{
Activation of GSK3 Prevents Termination of TNF-Induced Signaling
}

\author{
Bastian Welz* \\ Rolf Bikker (D* \\ Leonie Hoffmeister \\ Mareike Diekmann (D) \\ Martin Christmann (D) \\ Korbinian Brand* \\ René Huber (D)* \\ Institute of Clinical Chemistry, Hannover \\ Medical School, Hannover, 30625, \\ Germany \\ *These authors contributed equally to \\ this work
}

Correspondence: Korbinian Brand Institute of Clinical Chemistry, Hannover Medical School, Carl-Neuberg Str. I, Hannover, 30625, Germany

Tel +495II 5326614

Fax +49 5II 5328614

Email brand.korbinian@mh-hannover.de
Background: Termination of TNF-induced signaling plays a key role in the resolution of inflammation with dysregulations leading to severe pathophysiological conditions (sepsis, chronic inflammatory disease, cancer). Since a recent phospho-proteome analysis in human monocytes suggested GSK3 as a relevant kinase during signal termination, we aimed at further elucidating its role in this context.

Materials and Methods: For the analyses, THP-1 monocytic cells and primary human monocytes were used. Staurosporine (Stauro) was applied to activate GSK3 by inhibiting kinases that mediate inhibitory GSK3 $\alpha / \beta$-Ser21/9 phosphorylation (eg, PKC). For GSK3 inhibition, Kenpaulone (Ken) was used. GSK3- and PKC-siRNAs were applied for knockdown experiments. Protein expression and phosphorylation were assessed by Western blot or ELISA and mRNA expression by $\mathrm{qPCR}$. NF- $\kappa \mathrm{B}$ activation was addressed using reporter gene assays.

Results: Constitutive GSK $3 \beta$ and PKC $\beta$ expression and GSK $3 \alpha / \beta-\operatorname{Ser} 21 / 9$ and PKC $\alpha / \beta$ IIThr638/641 phosphorylation were not altered during TNF long-term incubation. Stauroinduced GSK3 activation (demonstrated by $\mathrm{Bcl} 3$ reduction) prevented termination of TNF-induced signaling as reflected by strongly elevated IL-8 expression (used as an indicator) following TNF long-term incubation. A similar increase was observed in TNF shortterm-exposed cells, and this effect was inhibited by Ken. PKC $\alpha / \beta-k n o c k d o w n$ modestly increased, whereas GSK3 $\alpha / \beta$-knockdown inhibited TNF-induced IL-8 expression. TNFdependent activation of two NF- $\kappa \mathrm{B}$-dependent indicator plasmids was enhanced by Stauro, demonstrating transcriptional effects. A TNF-induced increase in p65-Ser536 phosphorylation was further enhanced by Stauro, whereas $\operatorname{I\kappa B} \alpha$ proteolysis and IKK $\alpha / \beta-\operatorname{Ser} 176 / 180$ phosphorylation were not affected. Moreover, PKC $\beta$-knockdown reduced levels of $\mathrm{Bcl} 3$. $\mathrm{A} 20$ and $\mathrm{I} \kappa \mathrm{B} \alpha$ mRNA, both coding for signaling inhibitors, were dramatically less affected under our conditions when compared to IL-8, suggesting differential transcriptional effects. Conclusion: Our results suggest that GSK3 activation is involved in preventing the termination of TNF-induced signaling. Our data demonstrate that activation of GSK3 - either pathophysiologically or pharmacologically induced - may destroy the finely balanced condition necessary for the termination of inflammation-associated signaling.

Keywords: TNF, GSK3, PKC, staurosporine, IL-8, NF-kB, termination of TNF-induced signaling, termination of inflammation

\section{Introduction}

Following acute inflammation, a controlled and well-balanced resolution of the inflammatory process is required. ${ }^{1,2}$ The resolution phase further appears to be a necessary prerequisite for the subsequent establishment of the adaptive immune response and immunological memory in the post-resolution phase. ${ }^{2}$ Dysregulations 
in the attenuation phase may result in excessive inflammation such as septic shock and on the other side in chronic inflammatory diseases and autoimmunity, also including the development of immune paralysis. ${ }^{2,3}$ In addition, the contribution of inflammation to the development of cancer has been recognized as an important concept which is, however, only partially understood. ${ }^{4}$ The coordinated termination of inflammation involves a series of different, mutually supporting molecular mechanisms ${ }^{5}$ including the inhibition or controlled expression of pro- and anti-inflammatory cytokines and chemokines, ${ }^{6}$ shifts in metabolic processes, $^{7}$ and apoptosis. ${ }^{8}$ Moreover, tissue repair processes $^{9}$ and the development of different forms of tolerance towards stimulating agents such as tumor necrosis factor (TNF) may play a role. ${ }^{10}$ Leukocytes of the myelomonocytic lineage, especially monocytes and macrophages, are decisive players in maintaining tissue homeostasis and initiating/perpetuating inflammation, but also appear to be critically involved in resolving inflammatory events. ${ }^{11}$

Exposure to TNF leads to a dramatic activation of cells via pro-inflammatory signaling pathways. ${ }^{12,13}$ An essential step in the controlled restriction of inflammation is the termination of pro-inflammatory cytokine-induced signaling. ${ }^{5}$ For instance, it has been demonstrated that TNF-dependent signaling is restricted at multiple levels, eg, affecting nuclear factor $\kappa \mathrm{B}(\mathrm{NF}-\kappa \mathrm{B})^{14}$ which is stringently suppressed over time to a low amount of constitutive activation by various mechanisms. ${ }^{15}$ The expression of A20 is significantly induced during long-term TNF incubation leading to the persistent repression of TNF receptor type 1 (TNFR1-)dependent signal transduction. ${ }^{16}$ Under these conditions, the activation of the inhibitor of

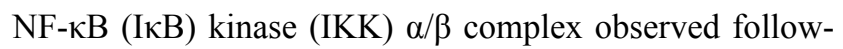
ing short-term TNF stimulation ${ }^{17}$ is completely inhibited in an A20-dependent manner. Downstream, increased NF$\kappa \mathrm{B}$ p50 and decreased p65 levels and p65-Ser536 phosphorylation were observed. ${ }^{18}$ Moreover, TNF long-term incubation induces the association of $\mathrm{p} 65$ with the transcription factor CCAAT/enhancer binding protein (C/EBP) $\beta$, an effect presumably contributing to the limitation of activating p65-Ser536 phosphorylation under these conditions. ${ }^{19}$

Our recent (phospho-)proteome analysis of long-term TNF-incubated monocytic cells suggests that glycogen synthase kinase (GSK) 3 represents a crucial kinase regulating the phosphorylation status and associated molecular functions orchestrating the termination of inflammation- induced signaling. ${ }^{20}$ In addition, by controlling the activation of various transcription factors including NF- $\kappa B$ and $\mathrm{C} /$ EBP, GSK3 is strongly involved in the transcriptional regulation of gene expression. ${ }^{21-23}$ GSK3 consists of two highly similar paralogues $(\alpha$ and $\beta$ ) and is predominantly controlled via inhibitory phosphorylation at Ser21 (GSK3 $\alpha$ ) or Ser9 (GSK3 $\beta$ ) by kinases such as protein kinase (PK)C $\alpha$ and $\beta$ or $\mathrm{PKB} / \mathrm{Akt}^{24-26}$ Due to its pro-inflammatory properties, GSK3 is regarded as a kinase promoting inflammation and it is well established that enzymatically active GSK3 acts as a potent driver of acute inflammation. ${ }^{26}$ GSK3 also mediates anti-inflammatory effects and may thus contribute to the balancing of both promotion and resolution of inflammation. ${ }^{26}$ Its detailed role within the termination of inflammation-associated signaling, however, is still not completely understood. Thus, this study aims at further elucidating the potential role of GSK3 in TNF-induced signaling. Our results suggest that an increased GSK3 activity level may be associated with an impaired termination of TNF-induced signaling. Based on our results, it is reasonable to hypothesize that any increase in (otherwise constitutive) GSK3 activity, either (patho-)physiologically or pharmacologically induced, results in a dysregulation of the well-balanced molecular network necessary for finetuning inflammation-associated signaling.

\section{Materials and Methods Isolation of Primary Human Monocytes and Cell Culture}

Freshly obtained blood samples from healthy donors were provided by the Institute of Transfusion Medicine, Hannover Medical School. Informed patient consent was obtained, and the experiments were approved by the Hannover Medical School ethics committee in accordance with the Declaration of Helsinki. Monocytes were isolated by initial Biocoll (Biochrom, Berlin, Germany) density gradient centrifugation in LeucoSep tubes (Greiner BioOne, Frickenhausen, Germany), followed by isolation of monocytes using a negative selection protocol (Monocyte Isolation Kit II; Miltenyi Biotec, Bergisch Gladbach, Germany), according to manufacturer's instructions as previously described. ${ }^{18}$ In short, non-monocytic cells were labelled via a combination of biotin-coupled primary monoclonal antibodies (directed against CD3, CD7, CD16, CD19, CD56, CD123, and Glycophorin A) and a magnetic microbead-conjugated secondary monoclonal anti-biotin antibody. The labelled non-monocytic cells were 
subsequently removed via a magnetic cell separation (MACS) column in a magnetic MACS separator (Miltenyi Biotec) yielding highly enriched monocytes (purity $>90 \%$, assessed by flow cytometry; see below).

Primary human monocytes, human monocytic THP1 cells, and HeLa cells (Deutsche Sammlung von Mikroorganismen und Zellkulturen, Braunschweig, Germany) were maintained in endotoxin-free Roswell Park Memorial Institute (RPMI) 1640 medium supplemented with $100 \mathrm{U} / \mathrm{mL}$ penicillin, $100 \mathrm{mg} / \mathrm{mL}$ streptomycin (Biochrom, Berlin, Germany), and 7.5\% fetal calf serum (Sigma Aldrich, St. Louis, USA). Medium for primary monocytes was additionally supplemented with $2 \%$ oxaloacetate/pyruvate/insulin media supplement (Sigma Aldrich) and 1\% minimum essential medium non-essential amino acids solution (Thermo Fisher, Bonn, Germany). THP-1 cells and primary human monocytes were cultured at a density of $5 \times 10^{5}$ cells/ well in 12 well plates, HeLa were plated at $2 \times 10^{5}$ cells/well in 6 well plates (Sarstedt, Nümbrecht, Germany). ${ }^{27}$

\section{Flow Cytometry}

The purity of freshly isolated primary monocytes was assessed by dual cell labeling for $30 \mathrm{~min}\left(4^{\circ} \mathrm{C}\right.$, dark) using Alexa Fluor405-CD45 (Invitrogen, Darmstadt, Germany) and allophycocyanin-CD14 (BD Biosciences, Heidelberg, Germany) recombinant human antibodies. Contamination with other leukocytes was excluded using the antibodies allophycocyanin-CD3, PE-CD19, FITCCD56 (BD Biosciences), and FITC-CD15 (Invitrogen). For detection, a FACSCanto II flow cytometer and the FACSDiVa software (BD Biosciences) were applied.

\section{Reagents}

For stimulation and long-term incubation experiments, TNF from Sigma Aldrich was used. To suppress protein degradation in cell lysates, the complete ethylenediaminetetraacetic acid-free protease inhibitor cocktail (Roche, Rotkreuz, Switzerland) was applied. Inhibitor experiments were performed using the kinase inhibitor Staurosporine (Stauro) and the GSK $3 \alpha / \beta$ inhibitor Kenpaullone (Ken; Sigma Aldrich). For Western blotting, antibodies specific for PKC $\beta$ (D3E70), p-PKC $\alpha / \beta \mathrm{II}$ (Thr638/641), GSK3 $\beta$ (27C10), p-GSK3 $\alpha / \beta$ (Ser21/9), p65 (L8F6), p-p65 (Ser536), IKK $\alpha$, p-IKK $\alpha / \beta$ (Ser176/ 180), IкB $\alpha$ (44D4; Cell Signalling, Danvers, USA), B cell lymphoma (Bcl) 3 (150-3.5; Santa Cruz
Biotechnology, Santa Cruz, USA), actin, and glyceraldehyde-3-phosphate dehydrogenase (GAPDH; SigmaAldrich) were used. Horseradish peroxidase-coupled secondary antibodies were purchased from Cell Signalling or Santa Cruz. All media and reagents were of the best available grade and routinely tested for endotoxins with the Limulus Amoebocyte Lysate assay (Lonza, Basel, Switzerland).

\section{Protein Extraction, SDS-PAGE, Western Blot Analysis, and Densitometry}

Preparation of whole-cell and nuclear extracts, determination of protein concentrations, electrophoresis, and Western blotting were performed as described: ${ }^{20,27}$ cells were lysed in extraction buffer $\mathrm{P}$ (8 $\mathrm{M}$ urea, 4\% 3-[(3-Cholamidopropyl)-dimethylammonio]-propanesulfonate (Sigma-Aldrich), $30 \mathrm{nM}$ Tris, 1\% Nonidet P-40 (AppliChem, Darmstadt, Germany), 1\% HALT phosphatase inhibitor (Thermo), and EDTA-free cOmplete protease inhibitor (Sigma-Aldrich) cocktails). To obtain nuclear proteins, cells were additionally sonicated (10 s, $20 \%$ power; Bandelin, Berlin, Germany). To gain sufficient amounts of proteins from primary human monocytes, cell lysates of monocytes derived from 2 independent individuals were pooled for subsequent Western Blot analyses. Protein concentration was determined via Bradford Assay (BioRad, Hercules, USA) and SDS-PAGE was performed using 10\% (proteins $\geq 50 \mathrm{kDa}$ ), 12\% (proteins $30-50 \mathrm{kDa}$ ), or $15 \%$ (proteins $\leq 30 \mathrm{kDa}$ ) Tris/GlycinSDS-polyacrylamide gels (Biostep, Jahnsdorf, Germany). Subsequently, proteins were transferred onto $45 \mu \mathrm{m}$ nitrocellulose membranes (BioRad) using the Western blot technique (transfer buffer: $200 \mathrm{mM}$ glycin (Applichem) and $25 \mathrm{mM}$ Tris-base, $\mathrm{pH}$ 8.3). For washing of membranes, Tris buffered saline (TBS) with $0.1 \%$ Tween (Sigma-Aldrich) (TBST) was used. After blocking with 5\% skim milk (Merck Millipore) or bovine serum albumin (BSA, Roche) in TBST, membranes were incubated overnight with specific primary antibodies at $4^{\circ} \mathrm{C}$ (diluted in milk-TBST or BSA-TBST according to the manufacturers' instructions). Following incubation with horseradish peroxidase-coupled secondary antibodies, protein bands were visualized using enhanced chemiluminescence (ECL; Thermo Fisher) or WesternBright Sirius (Advansta, Menlo Park, USA) and the Bio-imaging system ECL Chemostar (Intas Science Imaging, Göttingen, Germany). Densitometric analyses of gel band intensities were 
performed using the Image Studio Lite 5.2 software (LICOR Biosciences GmbH, Bad Homburg, Germany).

\section{Enzyme-Linked Immunosorbent Assay (ELISA)}

Culture supernatants were harvested, diluted 1:10 with phosphate buffered saline (PBS), and protein amounts of TNF were measured using the human TNF ELISA MAX Standard (BioLegend, San Diego, USA) according to manufacturer's instructions. Absorbance was determined with the ELx808 Absorbance Microplate Reader (BioTek Instruments, Bad Friedrichshall, Germany).

\section{RNA Extraction, cDNA Synthesis, and qPCR}

Cell lysis, RNA extraction, cDNA synthesis, and qPCR were performed as previously described. ${ }^{18,28}$ For cell lysis and total RNA isolation, the RNeasy Mini kit (Qiagen, Hilden, Germany) was applied according to the manufacturer's instructions. RNA concentration and purity were assessed using the Nanodrop ND-1000 (PeqLab Biotechnologie, Erlangen, Germany). Subsequently, one $\mu \mathrm{g}$ total RNA was reverse-transcribed using the Prime Script RT Master Mix (Takara, Saint-Germain-en-Laye, France) as indicated in the instructions. qPCR was performed on a LightCycler 480 (Roche) using the Takyon No ROX SYBR 2X MasterMix blue dTTP kit (Eurogentec, Seraing, Belgium). The following primers (Sigma Aldrich) were applied: CXC motif chemokine ligand (CXCL) 8 (ie, interleukin (IL-)8; 5'-TCCTGAT TTCTGCAGCTCTGTG-3', 5'-GGTCCACTCTCAATCA CTCTC-3'), tumor necrosis factor $\alpha$-induced protein (TNFAIP) 3 (ie, A20; 5'-CGGAAGCTTGTGGCGCTG AA-3', 5'-AGAGACTCCAGTTGCCAGCGG-3'), and NF- $\kappa B$ inhibitor $\alpha$ (NFKBIA, ie, I $\kappa \alpha ; 5$ '-CGAGCA GATGGTCAAGGAGC-3', 5'-CAGCCAAGTGGAGTG GAGTC-3'). Target gene expression levels were normalized to $\quad \beta 2$-microglobulin (5'-TGTGCTCG CGCTACTCTCTCTT-3', 5'-CGGATGGATGAAACCCA GACA-3'). Graphical representation of qPCR data was performed using GraphPad Prism 5.0 (GraphPad Software, La Jolla, USA).

\section{siRNA Transfection Experiments}

siRNA specific for PKC $\alpha$ (Silencer Select siRNA, Thermo Fisher), PKC $\beta$ (Silencer Select siRNA, Thermo Fisher or FlexiTube GeneSolution siRNA,
Qiagen, Hilden, Germany), GSK $3 \alpha$, and GSK3 $\beta$ (FlexiTube GeneSolution siRNA; Qiagen) was applied (negative control: Alexa Fluor 488-coupled AllStars siRNA, Qiagen). $2 \times 10^{5} \mathrm{HeLa}$ cells/well (in $500 \mu \mathrm{L}$ RPMI $1640+7.5 \%$ FCS, 6-well plates) were transfected overnight using X-tremeGENE siRNA Transfection Reagent (Roche) or HiPerFect transfection reagent (Qiagen) according to manufacturers' instructions: transfection reagent and (i) $100 \mathrm{nM}$ of single PKC or GSK3 siRNAs or (ii) $50 \mathrm{nM}$ siRNA each (when $\mathrm{PKC} \alpha / \beta$ or $\mathrm{GSK} 3 \alpha / \beta$ siRNAs were combined; volume ratio reagent to nucleic acid: $3: 1)$ were preincubated in $100 \mu \mathrm{L}$ Opti-MEM I (Thermo Fisher) for 30 min and then added to the cells. Subsequently, transfected cells were stimulated for $2 \mathrm{~h}$ or $48 \mathrm{~h}$ with $80 \mathrm{ng} /$ $\mathrm{mL}$ TNF and qPCR or Western Blot analyses were performed (see above).

\section{Dual-Luciferase Reporter Assay}

$2 \times 10^{5} \mathrm{HeLa}$ cells/well (in $2 \mathrm{~mL}$ RPMI $1640+7.5 \%$ FCS, 6-well plates; 2 wells per condition) were cotransfected with either the human IL-8 promoter-dependent firefly luciferase reporter gene vector pGL2 IL-8 luc (containing $420 \mathrm{bp}$ of the human IL-8 promoter) or the

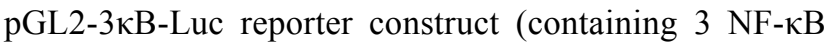
consensus binding sites) and the Renilla luciferase expressing transfection control pRLtk-Renilla ${ }^{29}$ using $\mathrm{X}$-treme gene HP transfection reagent (Roche) according to the manufacturer's instructions: transfection reagent and $1 \mu \mathrm{g}$ plasmids (900 $\mathrm{ng}$ reporter and $100 \mathrm{ng}$ control plasmid; volume ratio reagent to nucleic acid: $3: 1$ ) were preincubated in $100 \mu \mathrm{L}$ Opti-MEM I (Thermo Fisher) for $30 \mathrm{~min}$ and then added to the cells for 16 h. Following preincubation with $20 \mathrm{nM}$ Stauro for 30 min and subsequent stimulation with $80 \mathrm{ng} / \mathrm{mL}$ TNF for $6 \mathrm{~h}$, cells were lysed and whole cell extracts were prepared (see above). For analyses, extracts of 2 wells were combined per condition. Expression of Firefly and Renilla luciferase was determined in an Orion L microplate Luminometer (Berthold Detection Systems, Pforzheim, Germany) using the DualLuciferase Reporter Assay system (Promega, Mannheim, Germany) according to manufacturer's instructions. Results were indicated as relative luciferase activity (RLA), ie, Firefly relative light units were divided by Renilla relative light units. ${ }^{19}$ 


\section{Results}

Constitutive Expression of GSK3 $\beta$ and

PKC $\beta$ as Well as Phosphorylation of

GSK $3 \alpha / \beta$ (Ser2I/9) and PKC $\alpha / \beta I I$ (Thr638/64I) are Not Altered During

\section{TNF long-Term Incubation}

(Phospho-)proteome analysis of long-term TNF-incubated (48 h) primary monocytes identified a significant amount of phosphorylated proteins with binding motives for GSK $3 \alpha / \beta .{ }^{20}$ Therefore, in initial experiments, THP-1 monocytic cells were short- and long-term incubated \pm 80 $\mathrm{ng} / \mathrm{mL}$ TNF up to $48 \mathrm{~h}$ (for TNF levels in the supernatant over time, see Figure S1) and the phosphorylation status of GSK $3 \alpha / \beta$ (Ser21/9) and GSK3 $\beta$ protein levels were monitored (Figure 1). These experiments demonstrate that protein expression of GSK3 $\beta$ and phosphorylation of GSK $3 \alpha / \beta$ at the indicated phosphorylation sites were not changed during the complete $48 \mathrm{~h}$ TNF incubation interval (Figure 1A, left sides without inhibitor). Similar results were obtained when the level of PKC $\beta$ and the phosphorylation status of $\mathrm{PKC} \alpha / \beta \mathrm{II}$ (Thr638/641) were determined in both THP-1 (Figure 1B) and primary human monocytes (Figure 1C). The kinase PKC $\beta$ phosphorylates GSK3 $\beta$ at the inhibitory position Ser9 thus provoking the inhibition of GSK $3 \beta$ activity. ${ }^{26}$ Consistently, no increased GSK $3 \alpha / \beta$ Ser21/9 phosphorylation could be detected in primary monocytes (in relation to total protein amounts; Figure $\underline{\mathrm{S} 2}$ ). These data demonstrate that the constitutive expression of GSK3 $\beta$ and PKC $\beta$ as well as the phosphorylation of GSK3 $\alpha / \beta$ (Ser21/9) and PKC $\alpha / \beta$ II (Thr638/641) are not affected by TNF long-term incubation.

\section{Stauro Activates GSK3 $\beta$}

To study the role of GSK3 in TNF signaling, we used Stauro treatment as a model to increase the GSK3 activity level. Stauro inhibits kinases (eg, PKC) phosphorylating GSK3 $\beta$ on the inhibitory position Ser9. THP-1 cells were short/long-term incubated up to the indicated time points $\pm 80 \mathrm{ng} / \mathrm{mL} \mathrm{TNF}$, as already described above, in the absence/presence of $80 \mathrm{nM}$ Stauro, which was added 30 min before TNF incubation (Figure 1). Western Blot analysis showed that Stauro reduced the inhibitory GSK3 $\alpha / \beta$ Ser21/9 phosphorylation without affecting the expression level of GSK3 $\beta$ (Figure 1A, right side). To monitor GSK3 activity, the level of its substrate $\mathrm{Bcl} 3$ was determined (Figure 1D). GSK3 phosphorylates Bcl3 thus targeting it for proteasomal degradation. ${ }^{30,31}$ Our data show that the Bcl3 levels - which are induced by TNF long-term incubation, as shown earlier ${ }^{32}$ - were completely abolished by Stauro treatment (Figure 1D). Taken together, our data suggest that under our experimental conditions, Stauro strongly increases GSK3 activity.

\section{Stauro and PKC $\beta$ siRNA Prevent the Termination of Long-Term TNF-Induced IL-8 Expression}

As also shown earlier, ${ }^{15,18}$ incubation of monocytic THP-1 cells with TNF led to a strong increase in IL-8 mRNA (used as indicator for TNF-induced signaling; Figure 2) after $2 \mathrm{~h}$ which was significantly reduced at $24 \mathrm{~h}$ where it reached a low (ie, only weakly elevated over baseline) and virtually constant level until $48 \mathrm{~h}$ (Figure 2A). To determine the impact of Stauro-induced GSK3 activity on TNF signaling, THP-1 cells were long-term incubated for $24 \mathrm{~h} \pm 80 \mathrm{ng} / \mathrm{mL}$ TNF in presence of increasing doses of Stauro $(0-80 \mathrm{nM})$, and the IL-8 mRNA expression was analyzed (Figure 2B). This approach showed that Stauro dose-dependently enhanced IL-8 expression in long-term TNF-exposed cells with a maximal effect at $80 \mathrm{nM}$ of the concentrations tested (Figure 2B). In the absence of TNF, a modest effect of Stauro was also observed at higher doses. Similar effects were observed in primary human monocytes incubated $\pm \mathrm{TNF}$ for $48 \mathrm{~h}$ in the absence/presence of Stauro (Figure 2C). Since long-term TNF-stimulated monocytic cells are not able to properly respond to a subsequent challenge with $\mathrm{TNF}^{10}{ }^{10}$ we next determined whether Stauro also influences this desensitized state. Thus, THP-1 cells were preincubated for $48 \mathrm{~h}$ with TNF ( \pm Stauro) and then restimulated with TNF for $2 \mathrm{~h}$ (Figure 2D). Again, Stauro had a dramatic effect on long-term TNF-incubated cells, which was only slightly further influenced by restimulation (Figure 2D). Our data demonstrate that Stauro dramatically enhances IL-8 expression during long-term TNF incubation and, therefore, suggest that Stauro is able to prevent termination of TNF-induced signaling.

To further confirm the involvement of GSK3 in the regulation of IL-8 mRNA levels on a molecular level, we performed experiments with siRNA against the GSK3inhibiting kinase PKC $\beta$ (Figure 2E). HeLa cells were transfected overnight with siRNA directed against PKC $\beta$ and then incubated with TNF for $48 \mathrm{~h}$ (Figure 2E). Treatment with PKC $\beta$ siRNA led to a significant reduction 
A

\begin{tabular}{|c|c|c|c|c|c|c|c|c|c|c|c|}
\hline \multicolumn{6}{|c|}{ DMSO } & \multicolumn{6}{|c|}{ Stauro } \\
\hline 0 & 15 & 30 & 0 & 15 & 30 & 0 & 15 & 30 & 0 & 15 & 30 \\
\hline
\end{tabular}

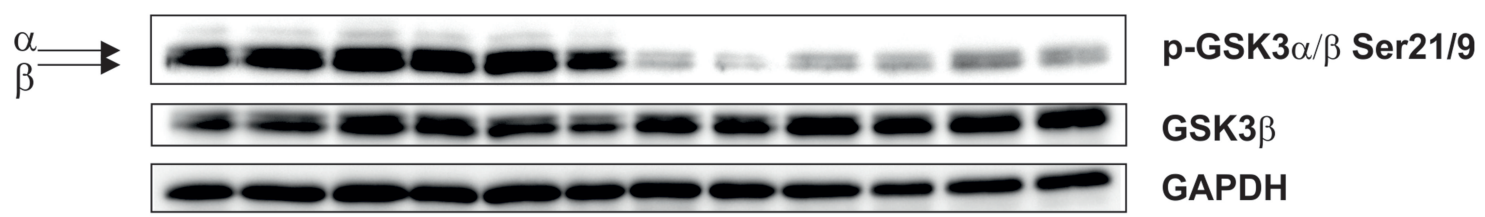

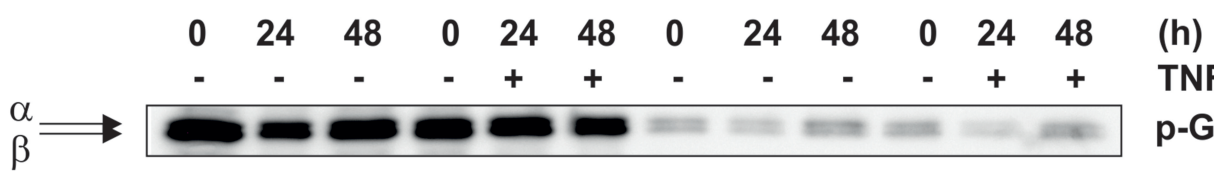

TNF

p-GSK3 $\alpha / \beta$ Ser21/9

b-

-

B
$\begin{array}{lllllll}0 & 6 & 12 & 24 & 36 & 48 & \text { (h) }\end{array}$
$-\overline{-}++\frac{24}{-++}+$ TNF

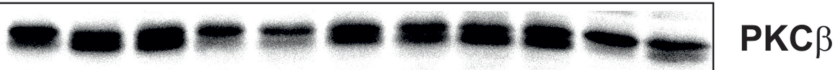

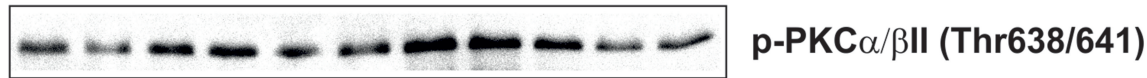

GAPDH

C

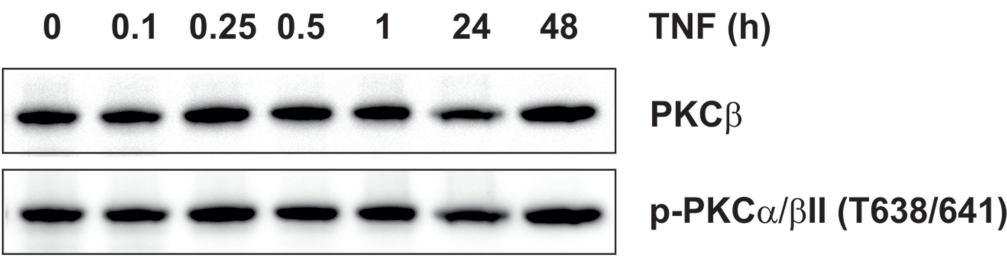

Actin

D

\begin{tabular}{|c|c|c|c|c|c|c|c|c|c|c|c|c|}
\hline \multicolumn{6}{|c|}{ DMSO } & \multicolumn{6}{|c|}{ Stauro } & \multirow[b]{2}{*}{ (h) } \\
\hline 0 & 24 & 48 & 0 & 24 & 48 & 0 & 24 & 48 & 0 & 24 & 48 & \\
\hline- & - & - & - & + & + & - & - & - & - & + & + & TNF \\
\hline 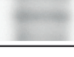 & \pm & $E$ &  & 8 & 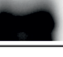 & tet &  & 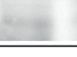 &  & 복 & C & $\mathrm{Bcl} 3$ \\
\hline
\end{tabular}

Figure I Stauro activates constitutive GSK3 during short/long-term TNF incubation. (A) Staurosporine (Stauro) reduces inhibitory S2I/S9 phosphorylation of constitutive GSK3 $\alpha / \beta$. THP-I monocytic cells were incubated up to the indicated time points $\pm 80 \mathrm{ng} / \mathrm{mL}$ TNF $\pm 80 \mathrm{nM}$ Stauro (preincubation phase: $0.5 \mathrm{~h}$ ). The levels of $\mathrm{p}$-GSK3 $\alpha / \beta$ (Ser2I/9) and GSK3 $\beta$ were determined in whole cell extracts by Western Blot. (B-C) TNF has no influence on PKC $\beta$ protein expression and PKC $\alpha / \beta$ II phosphorylation (Thr638/64l) in monocytic cells during TNF long-term incubation. THP-I cells (B) or primary human monocytes (C) were incubated $\pm 80 \mathrm{ng} / \mathrm{mL}$ TNF up to the indicated time points. Levels of PKC $\beta$ and p-PKC $\alpha / \beta$ II (Thr638/64I) were determined in whole cell extracts. (D) Stauro reduces Bcl3 levels. THP-I cells were incubated as described in (A) and levels of Bcl3 were determined. (A, B, D) Loading control: GAPDH, n=3; (C) loading control: actin, $n=2$ (representative experiments). 

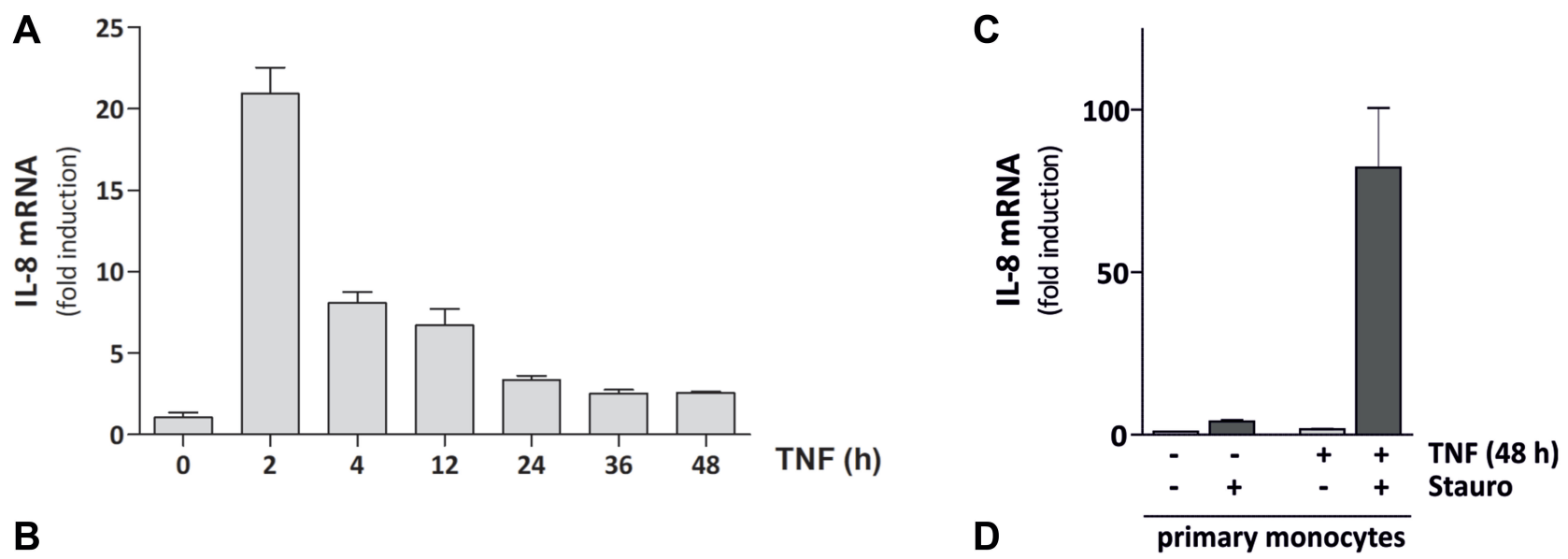

B

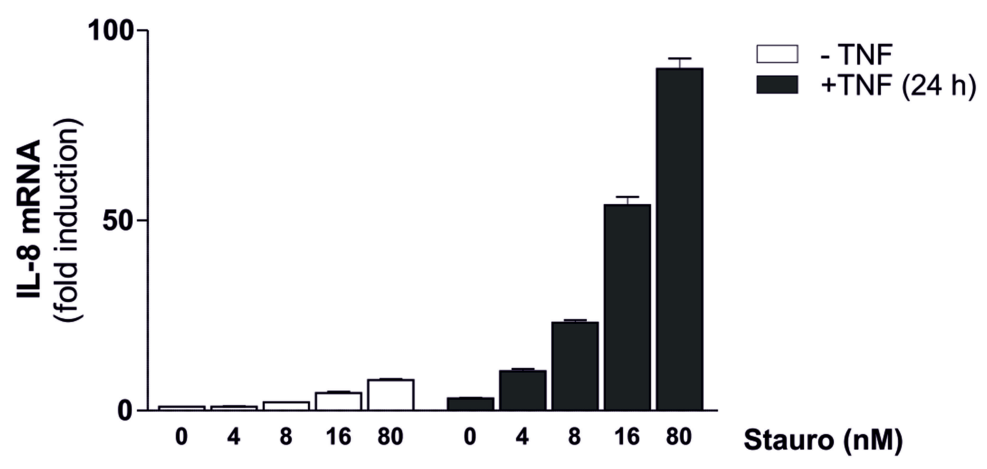

E

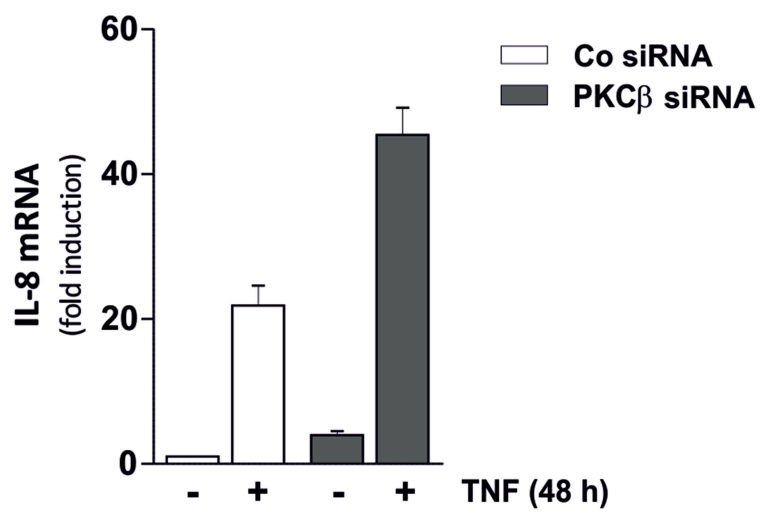

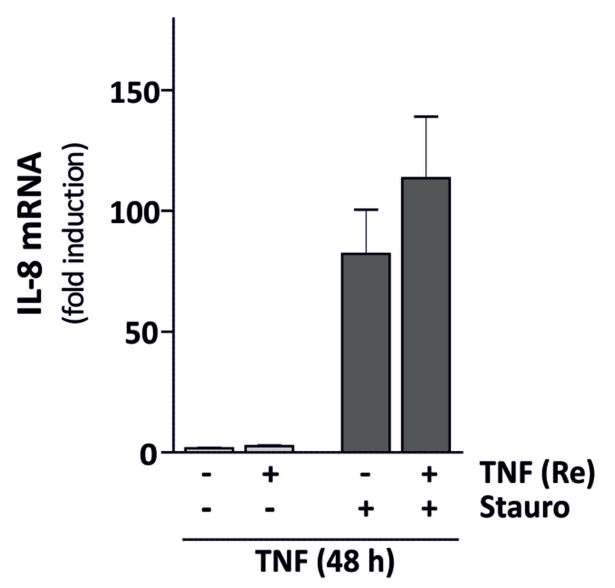

Figure 2 Stauro and PKC $\beta$ siRNA prevent the termination of long-term TNF-induced IL-8 expression. (A) Induction and termination of TNF-induced IL-8 expression. THP-I cells were incubated up to $48 \mathrm{~h}$ with $80 \mathrm{ng} / \mathrm{mL}$ TNF. The IL-8 mRNA expression was determined by qPCR at the indicated time points. (B) Stauro dose-dependently enhances IL-8 expression during long-term TNF exposure. THP-I cells were incubated for $24 \mathrm{~h} \pm 80 \mathrm{ng} / \mathrm{mL} \mathrm{TNF}$ in the presence of increasing doses of Stauro (0-80 nM, preincubation phase: $0.5 \mathrm{~h}$ ), and the IL-8 mRNA expression was determined (representative experiment, determined in triplicates). (C) Stauro dramatically increases IL-8 expression in long-term TNF-incubated primary human monocytes. Primary human monocytes were treated for $48 \mathrm{~h} \pm 80 \mathrm{ng} / \mathrm{mL}$ TNF and $\pm 80 \mathrm{nM}$ Stauro (preincubation phase: $0.5 \mathrm{~h}$ ). Afterwards, the IL-8 mRNA expression was determined. (D) Stauro increases IL-8 mRNA expression during TNF long-term incubation but has no further influence on IL-8 expression following TNF restimulation. THP-I cells were pretreated for 48 $\mathrm{h}$ with $80 \mathrm{ng} / \mathrm{mL}$ TNF and $\pm 80 \mathrm{nM}$ Stauro (preincubation phase: $0.5 \mathrm{~h}$ ). Subsequently, cells were restimulated (Re) for $2 \mathrm{~h} \pm 80 \mathrm{ng} / \mathrm{mL}$ TNF, and the IL- $8 \mathrm{mRNA}$ expression was measured. For $(\mathbf{A}-\mathbf{D})$ the induction value of cells cultivated in medium in the absence of TNF or Stauro was defined as I and mean \pm SD ( $=3$ ) is shown. (E) Long-term TNF-mediated IL-8 expression is enhanced by PKC siRNA. HeLa cells were transfected overnight with scrambled (Co) or PKC $\beta$ siRNA. Subsequently, cells were stimulated $\pm 80 \mathrm{ng} / \mathrm{mL}$ TNF for $48 \mathrm{~h}$ or cultivated in medium and IL-8 expression was monitored. IL-8 expression in Co siRNA-transfected cells $(-T N F)$ was set as I (triplicates, representative for $n=3$; mean $\pm S D$ ). 
of PKC $\beta$ protein and mRNA levels (Figure S3A and $\underline{B}$ ). The presence of PKC $\beta$ siRNA induced a modest elevation of TNF-induced IL-8 expression (Figure 2E).

\section{Stauro Increases IL-8 mRNA Expression During TNF Short-Term Incubation Which is Blocked by a GSK3 Inhibitor}

To further examine how Stauro influences TNF-induced IL-8 mRNA expression and also to demonstrate an involvement of GSK3, we assessed the effect of Stauro on TNF short-term incubation. THP-1 cells were incubated for 2 $\mathrm{h} \pm 80 \mathrm{ng} / \mathrm{mL}$ TNF in the presence of increasing doses of Stauro (Figure 3A). Again, a dramatic dose-dependent effect of Stauro on TNF-induced IL-8 expression was observed (Figure 3A). During short-term incubation, a maximal effect of Stauro was reached between 8 and $20 \mathrm{nM}$ (Figure 3A, data not shown). The fact that Stauro also dramatically affects TNF short-term incubation suggests that very fast transcriptional mechanisms play a significant role in this context. To confirm that increased GSK3 activity participates in Stauro-mediated effects on TNF signaling, THP-1 cells were preincubated with the GSK3 inhibitor Ken (Figure 3B) and further experimental conditions were applied as described in Figure 3A. These experiments showed that Ken almost completely blocked the dramatic Stauro-mediated enhancement of TNF-stimulated IL-8 mRNA expression (Figure 3B) suggesting a major involvement of GSK3.

\section{IL-8 Expression is Increased by PKC Knockdown and Reduced by GSK3 Knockdown}

In the next experiments, to validate the involvement of GSK3 in the regulation of IL-8 mRNA levels during shortterm TNF stimulation (Figure 3C and D), HeLa cells were transfected overnight with siRNA directed against $\mathrm{PKC} \alpha$, $\mathrm{PKC} \beta$, or both, and then incubated with TNF for $2 \mathrm{~h}$ (Figure 3C). Comparable with the results obtained
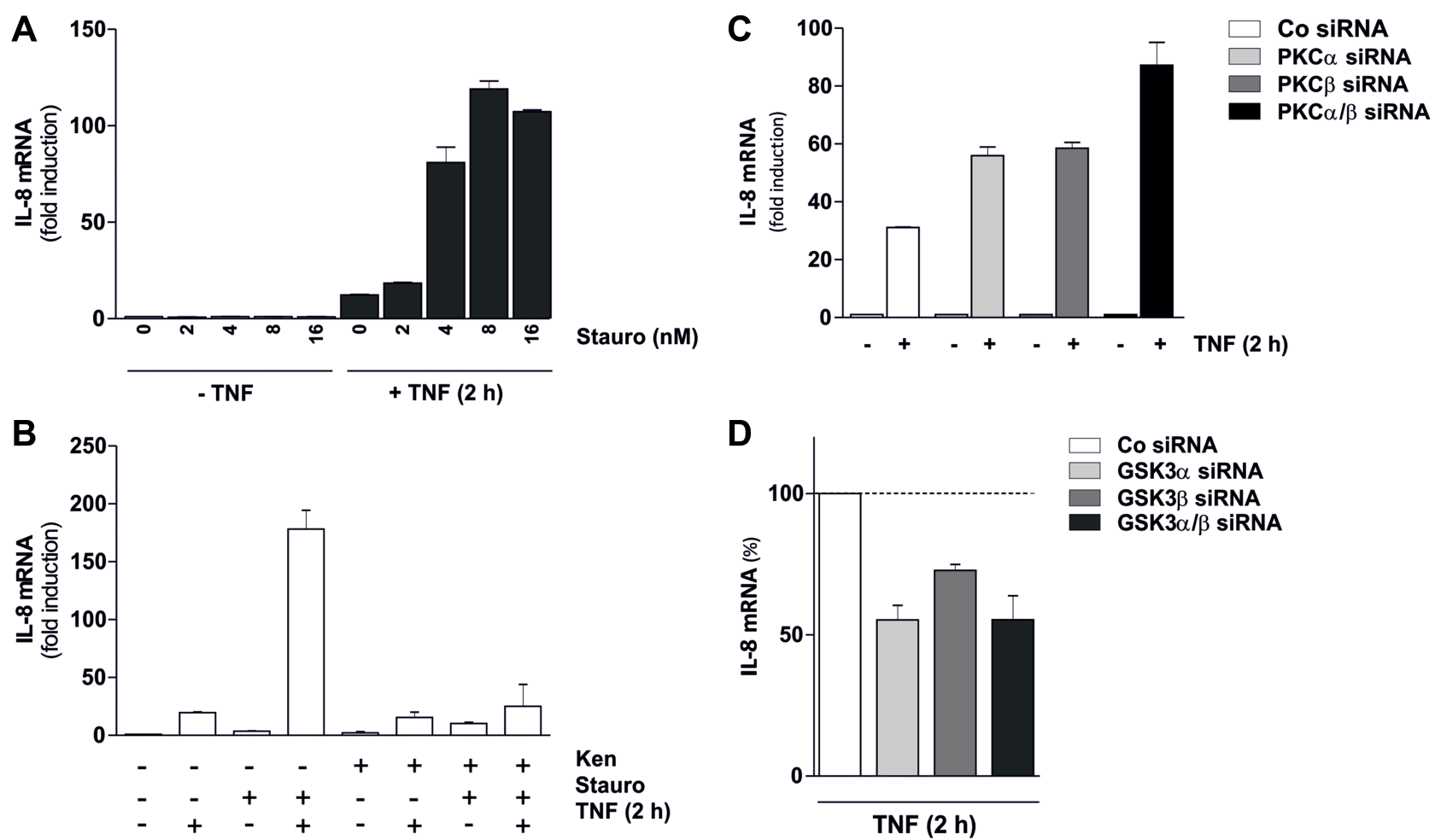

Figure 3 Effects of Stauro on TNF short-term incubation and involvement of GSK3. (A) Stauro increases IL-8 mRNA expression during TNF short-term incubation. THP-I cells were incubated for $2 \mathrm{~h} \pm 80 \mathrm{ng} / \mathrm{mL}$ TNF in the presence of increasing doses of Stauro (0-16 nM, preincubation phase: $0.5 \mathrm{~h}$ ). The IL-8 mRNA expression was determined by qPCR (triplicates, representative for at least 3 experiments; mean \pm SD). (B) The effects of Stauro on TNF-stimulated IL-8 expression are blocked by a GSK3 inhibitor. THP-I cells were incubated for $2 \mathrm{~h} \pm 80 \mathrm{ng} / \mathrm{mL}$ TNF, $\pm 2.5 \mu$ M Kenpaullone (Ken; preincubation phase: I h), and $\pm 20 \mathrm{nM}$ Stauro (preincubation phase: 0.5 h). The IL-8 mRNA amounts were determined using qPCR (triplicates, representative for $n=3$; mean \pm SD). (C) Short-term TNF-mediated expression of IL-8 is enhanced by PKC siRNA. HeLa cells were transfected overnight with scrambled (Co) siRNA or siRNA directed against PKC $\alpha$, PKC $\beta$, or both. Subsequently, cells were stimulated $\pm 80 \mathrm{ng} / \mathrm{mL}$ TNF for $2 \mathrm{~h}$ or cultivated in medium and IL-8 expression was monitored (triplicates, representative for $n=3$ using different siRNAs; mean \pm SD). (D) TNF-mediated expression of IL-8 is reduced by GSK3 siRNA. HeLa cells were transfected overnight with Co siRNA or siRNA directed against GSK $3 \alpha$, GSK $3 \beta$, or both. Subsequently, cells were stimulated \pm 80 $\mathrm{ng} / \mathrm{mL}$ TNF for $2 \mathrm{~h}$. TNF-induced IL-8 expression in Co siRNA-transfected cells was set as 100\% (triplicates, representative for $\mathrm{n}=3$; mean \pm SD). 
following long-term TNF incubation, PKC $\alpha / \beta$ siRNA induced a modest increase in TNF-induced IL-8 mRNA levels (Figure 3C). Afterwards, cells were also transfected with siRNA against GSK3 $\alpha$, GSK3 $\beta$, or both (Figure 3D) and subsequently stimulated with TNF for $2 \mathrm{~h}$ (for knockdown of $\mathrm{PKC} \alpha / \beta$ and GSK $3 \alpha / \beta$ by siRNA, see Figure S3A and B). Again, treatment of cells with GSK3 siRNA reduced the expression of IL- 8 (Figure 3D). The data obtained using different siRNAs are consistent with the results obtained with Ken as described above and suggest that increased GSK3 activity is involved in the enhancement of short-term TNF signaling.

\section{Transcriptional Effects of Stauro and PKC $\beta$ siRNA}

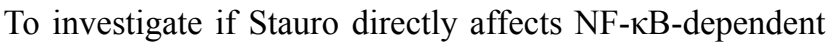
transcription, HeLa cells were transfected with an IL-8 promoter- as well as a $3 \kappa \mathrm{B}$-dependent indicator plasmid (Figure 4A). Subsequently, cells were preincubated with Stauro followed by TNF stimulation for $6 \mathrm{~h}$. Both indicator plasmids were activated by TNF, an effect which was further enhanced by Stauro (Figure 4A). A weak induction of reporter gene expression was detected in the presence of Stauro alone. In the next steps, we further explored the transcriptional mechanisms involved in the effects described above. It has been shown that GSK3 phosphorylates p65-Ser536. ${ }^{33}$ Therefore, THP-1 cells were shortterm incubated with $\mathrm{TNF} \pm$ Stauro and the protein levels of p65 and p-p65 (Ser536) were determined (Figure 4B). TNF induced an increase in p65 phosphorylation at 10 min (Figure 4B), an effect further increased by Stauro. Under similar conditions, proteolysis of I $\kappa \mathrm{B} \alpha$ and phosphorylation of IKK $\alpha / \beta$ (Ser176/180) were not affected (Figure 4C and D). In a second set of experiments, HeLa cells were transfected overnight with PKC $\beta$ siRNA (Figure 4E). Subsequently, the cells were stimulated with TNF up to $6 \mathrm{~h}$ and $\mathrm{Bcl} 3$ levels were determined. ${ }^{32}$ The presence of PKC $\beta$ siRNA considerably reduced the levels of this positive/negative regulatory transcription factor (Figure 4E). As expected, PKC $\beta$ siRNA reduced PKC mRNA and protein levels which was accompanied by reduced levels of $\mathrm{p}-\mathrm{GSK} 3 \alpha / \beta-\operatorname{Ser} 21 / 9$ (data not shown). $\mathrm{Bcl} 3$ has been suggested to inhibit IL-8 expression ${ }^{34,35}$ but may also be involved in the positive regulation of $\mathrm{A} 20^{36,37}$ and $\mathrm{I} \kappa \mathrm{B} \alpha{ }^{37,38}$ Therefore, THP-1 cells were incubated $\pm \mathrm{TNF}$ for $48 \mathrm{~h}$ in the absence/presence of Stauro (Figure 4F). After TNF incubation for $48 \mathrm{~h}$, very low expression levels of IL-8 (1,7-fold) and IאB $\alpha$ (2,1-fold) were detected when compared to A20 amounts (24,9-fold) (Figure 4F). As described above, following TNF long-term incubation, Stauro significantly increased IL-8 mRNA expression (Figure 4F). In contrast, no significant effect of Stauro on A20 and only a mild effect on I $\mathrm{B} \alpha$ mRNA expression were detected under this condition, suggesting differential transcriptional effects.

\section{Discussion}

The Janus-faced functionalities of the cellular multiprocessor GSK3 in the termination of inflammation-associated signaling are still not comprehensively understood. ${ }^{25,26}$ Since our recent (phospho-)proteome analysis of longterm TNF-incubated primary monocytes identified a significant amount of phosphorylated proteins with binding motives for GSK $3 \alpha / \beta$, we aimed at further assessing its role in the termination of TNF-induced signaling. ${ }^{20}$ Our data demonstrate a stable phosphorylation level of inhibitory GSK $3 \alpha / \beta$-Ser $21 / 9$ and a constitutive GSK3 $\beta$ expression in THP-1 monocytic cells which was not altered during short/long-term TNF incubation. GSK3 is constitutively active in most cell types ${ }^{39,40}$ including macrophages $^{41}$ and it has been shown earlier that in quiescent cells, GSK3 is characterized by basal activity. ${ }^{40,42}$ Moreover, a GSK3-mediated transcriptional network maintains repression of immediate early genes in quiescence cells $^{43}$ and plays a key role in maintaining the repression of growth factor-inducible genes. ${ }^{44}$ In TNFexposed cells, an at most weak regulation of GSK3 protein expression or phosphorylation has been found ${ }^{16,18,45-47}$ which is basically similar to our results. It has been shown that TNF does not markedly change basal activity or phosphorylation of GSK3 in macrophages ${ }^{16}$ but instead promotes nuclear translocation of active GSK3. The PKC isoforms $\alpha$ and $\beta$ are able to phosphorylate GSK $3 \alpha / \beta$ at the inhibitory Ser21/Ser9 residues. ${ }^{48}$ Our experiments further show that the constitutive expression of PKC $\beta$ and the activating phosphorylation of PKC $\alpha / \beta \mathrm{II}$ (Thr638/641) also remain constant in both THP-1 cells and primary human monocytes during TNF long-term exposure. For other cell types, eg, primary human umbilical vein endothelial cells or murine skeletal myotubes, an increased activation-associated phosphorylation of $\mathrm{PKC} \alpha / \beta$ in response to TNF has been reported. ${ }^{49,50}$ However, since TNF-dependent effects on PKC activation appear to be highly cell type-specific, ${ }^{51}$ the discrepancy between our results and the literature may result from the different 
A



B



F



C Stauro

\begin{tabular}{|c|c|c|c|c|c|c|c|c|c|c|c|c|}
\hline 0 & 5 & 15 & 30 & 60 & 120 & 0 & 5 & 15 & 30 & 60 & 120 & TNF (min) \\
\hline- & & & & 2 & - & 0 & 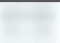 &  & & 24 & 2. & $\mathrm{I} K \mathrm{~B} \alpha$ \\
\hline
\end{tabular}

D

Co

Stauro

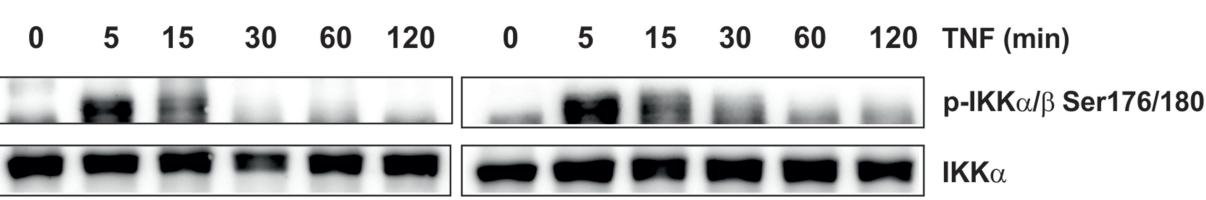

E

\begin{tabular}{|c|c|c|c|c|c|c|c|c|c|}
\hline \multicolumn{5}{|c|}{ Co } & \multicolumn{5}{|c|}{ PKC $\beta$} \\
\hline 0 & 0.5 & 1 & 2 & 6 & 0 & 0.5 & 1 & 2 & 6 \\
\hline & - & - & - & - & $=$ & - & - & & \\
\hline
\end{tabular}

SiRNA

TNF (h)

$\mathrm{Bcl} 3$

GAPDH

Figure 4 Transcriptional effects of Stauro and PKC $\beta$ siRNA. (A) Stauro enhances TNF-induced NF- $\kappa$ B-dependent gene expression. HeLa cells were transfected overnight with the vector control, the IL-8 promotor-, or the $3 \kappa B$-dependent firefly luciferase reporter gene construct (transfection control: Renilla luciferase expression vector $\mathrm{PRL}$ CMV). Subsequently, cells were preincubated $0.5 \mathrm{~h} \pm 20 \mathrm{nM}$ Stauro and afterwards stimulated $\pm 80 \mathrm{ng} / \mathrm{mL}$ TNF for $6 \mathrm{~h}$. Whole cell extracts were prepared and luciferase activity was determined. Data are presented as relative luciferase activity (RLA; triplicates, representative for at least 3 experiments; mean \pm SD). (B-D) Stauro increases p65-Ser536 phosphorylation but has no effect on IKB $\alpha$ proteolysis or IKK $\alpha / \beta$-Ser I76/I80 phosphorylation. THP-I cells were incubated up to the indicated time points with $80 \mathrm{ng} / \mathrm{mL}$ TNF and $\pm 20 \mathrm{nM}$ Stauro (preincubation phase: $0.5 \mathrm{~h}$; Co, untreated control.). The protein levels of (B) p-p65 (Ser536) and p65, (C) I $\mathrm{BB} \alpha$ (loading control: GAPDH), as well as (D) p-IKK $\alpha / \beta$ (Ser I 76/I80) and IKK $\alpha$ were determined by Western blot ((B) nuclear extracts; (C and $\mathbf{D})$ whole cell extracts; $n=3$ each, representative experiments). In panel $4 \mathrm{~B}$, band intensities as assessed by densitometry are provided under the respective bands (the band intensity of the control at $0 \mathrm{~h}$ was set as $\mathrm{I}$ ). (E) PKC $\beta$ siRNA reduces the level of Bcl3. HeLa cells were transfected overnight with scrambled (Co) or PKC $\beta$ siRNA. Subsequently, cells were stimulated with 80 ng/mL TNF up to $6 \mathrm{~h}$ and $\mathrm{Bcl} 3$ was determined in whole cell extracts ( $n=3$, representative experiment). (F) Differential effects of Stauro on IL-8, A20, and IKB $\alpha$ mRNA expression. THPI cells were incubated for $48 \mathrm{~h} \pm 80 \mathrm{ng} / \mathrm{mL}$ TNF. In the first $24 \mathrm{~h}$, cells were also treated $\pm 80 \mathrm{nM}$ Stauro. The mRNA levels of IL-8, A20, and IкB $\alpha$ were determined using qPCR. The expression level in cells cultivated in the absence of TNF and Stauro was defined as I ( $n=3$; mean \pm SD). 
cell types used. During the long-term TNF incubation applied in our study, TNF amounts in the supernatant remained on a well detectable level over time, with an only modest decrease up to $6 \mathrm{~h}$ (ie, approx. $40 \%$ reduction when compared to the initial TNF dose) and virtually stable levels between 6 and $48 \mathrm{~h}$. These data indicate that sufficient TNF amounts are present to maintain longterm TNF-dependent signaling. Furthermore, given that the half-life of TNF in serum is about $1 \mathrm{~h}$ (and even TNF stabilized by fusion to human serum albumin has a half-life of only $15 \mathrm{~h}){ }^{52}$ relatively stable TNF amounts in the late phase suggest that under this condition, exogenous TNF induces TNF expression and secretion by monocytic cells. Taken together, our results suggest a constant activation/expression of the $\mathrm{PKC} / \mathrm{GSK} 3$ system during TNF long-term exposure of monocytic cells.

To dysregulate this system, we used Stauro treatment as a model for GSK3 activation. Stauro is a naturally occurring bisindolylmaleimide acting as a potent ATPcompetitive inhibitor of GSK3-phosphorylating kinases such as $\mathrm{PKC}$ or $\mathrm{PKB} / \mathrm{Akt}$ which address the inhibitory amino acids Ser21/9. ${ }^{53-55}$ The present data show that under our condition, Stauro reduces this inhibitory GSK $3 \alpha / \beta$ phosphorylation without affecting protein expression levels. To monitor GSK3 activity, the level of the GSK3 substrate Bcl3 was determined. ${ }^{56}$ GSK3mediated phosphorylation targets $\mathrm{Bcl} 3$ for proteasomal degradation. ${ }^{31}$ Our results show that $\mathrm{Bcl} 3$ levels, which are induced by TNF incubation, are completely abolished by Stauro treatment. Taken together, these data suggest that we apply an experimental setting in which Stauro strongly increases the normal constitutive GSK3 activity in TNF-exposed cells.

Following the dramatic initial pro-inflammatory response towards $\mathrm{TNF}^{13}$ the long-term incubation with this cytokine leads to a sustained downregulation of TNF-dependent signal transduction and the termination of NF- $\mathrm{KB}$ activation within $48 \mathrm{~h}$ in cells of the myelomonocytic lineage. ${ }^{10}$ This phenomenon is also described as Phase III of TNF signaling. ${ }^{15}$ Our experiments show that Stauro dose-dependently enhances IL-8 expression in monocytic THP-1 cells and primary human monocytes during both long-term and short-term TNF incubation. However, when TNF long-term incubated cells were restimulated with TNF, Stauro had no further effect. The Stauro amounts used proved to be remarkably effective in our experiments and are in good agreement to the literature specifying 11 to $200 \mathrm{nM}$ as concentrations shown before to increase GSK3 activity. ${ }^{56,57}$ Using the GSK $3 \alpha / \beta$ inhibitor Ken, the Stauro-mediated dramatic enhancement of TNF-stimulated IL-8 expression was virtually blocked completely suggesting a major involvement of GSK3. This conclusion was supported by siRNA studies showing that the presence of $\mathrm{PKC} \alpha / \beta$ siRNA induced a modest elevation of TNF-induced IL-8 expression. Moreover, siRNA-mediated knockdown of GSK3 $\alpha$, GSK3 $\beta$, or both reduced IL-8 expression in TNF-stimulated cells. The data obtained using siRNAs are consistent with the results observed with Ken suggesting that increased GSK3 activity can lead to the enhancement of TNF signaling.

The fact that Stauro also dramatically affects TNF short-term incubation suggests that very fast transcriptional mechanisms play a significant role in mediating this effect. ${ }^{35}$ It has been demonstrated that under certain conditions, the early steps leading to NF- $\mathrm{KB}$ activation (degradation of I $\mathrm{I} B$ and translocation of NF- $\kappa \mathrm{B}$ to the nucleus) were unaffected by the loss of GSK $3 \beta^{21}$ indicating that NF- $\mathrm{KB}$ is regulated by GSK3 $\beta$ via the transcriptional complex. This assumption was substantiated by the fact that Stauro also enhanced the short-term TNF-induced activation of two NF-kB-dependent promoter constructs (IL-8 promoter, $3 \kappa \mathrm{B}$ ) in our study. Furthermore, it has been shown that TNF increases the nuclear accumulation of GSK $3 \beta$ and that nuclear GSK3 was active in TNFtreated cells phosphorylating Ser536 on p65. ${ }^{16,33}$ In our experiments, the TNF-induced increase in activating p65Ser536 phosphorylation was further increased when Stauro was added. Under similar conditions, the proteolysis of I $\mathrm{B} \alpha$ and the phosphorylation of IKK $\alpha / \beta$ (Ser176/180) were not affected. The presence of PKC $\beta$ siRNA reduced the levels of $\mathrm{Bcl} 3$ which is - as already mentioned ${ }^{30,31}$ phosphorylated by GSK3. Under this condition, we also detected lowered levels of inhibiting p-GSK3 $\alpha / \beta$ (Ser21/9) phosphorylation, suggesting an increase in GSK3 activity and an involvement of PKC in the regulation of GSK3 (data not shown). Bcl3 has been suggested to inhibit IL-8 expression $^{34,35}$ but may also be involved in the positive regulation of $\mathrm{A} 20^{36,37}$ and $\mathrm{I} \kappa \mathrm{B} \alpha{ }^{37,38}$ In contrast to the strong effect on TNF-mediated IL-8 expression, no significant effect of Stauro on A20 mRNA and only a weak effect on I $\mathrm{B} \alpha \alpha$ mRNA expression were detected, suggesting an involvement of $\mathrm{Bcl} 3$ and differential transcriptional effects.

Based on our results and the literature, several mechanisms on various levels comprising a dense network can be 
envisaged to assess how an increase in GSK3 activity might counteract the termination of TNF-induced signaling. GSK3 positively regulates the transcriptionally active p65 NF- $\kappa \mathrm{B}$ subunit, thereby increasing NF- $\kappa \mathrm{B}$-dependent gene expression. $^{21}$ On the other hand, GSK3 phosphorylation marks several potentially inhibitory proteins for proteasomal degradation including $\mathrm{Bcl} 3, \mathrm{p} 100, \mathrm{p} 105$, and v-rel reticuloendotheliosis viral oncogene homolog (Rel) B. ${ }^{26}$ GSK3 activation can also increase DNA binding capacity of NF- $\kappa \mathrm{B}$ subunits $^{21,33,58}$ and both TNF and GSK3 regulate chromatin accessibility. ${ }^{16}$ Furthermore, additional mechanisms are conceivable to explain how enhanced GSK3 activity may reduce the supply with several inhibitory molecules including p50 and the other inhibitory molecules mentioned above $^{31}$ during TNF long-term exposure. For example, $\mathrm{Bcl} 3$ restricts inflammation by both suppressing pro-inflammatory gene expression and inducing the expression of antiinflammatory cytokines. ${ }^{31}$ In macrophages, decreased levels of $\mathrm{Bcl} 3 / \mathrm{p} 52$ or $\mathrm{Bcl} 3 / \mathrm{p} 50$ complexes may reduce the expression of IL- $10^{59}$ which is an important cytokine involved in termination of inflammation-associated signaling. ${ }^{60} \mathrm{Bcl} 3$ also stabilizes $\mathrm{p} 50 / \mathrm{p} 50$ complexes that inhibit gene transcription. $^{31}$ Bcl3-deficient mice and knockout cells were found to be hypersensitive to TLR activation and unable to control responses to lipopolysaccharide. ${ }^{61}$ A lower amount of RelB/p52 may also lead to a reduced indolamin-2,3-dioxygenase expression, which would result in a shift from non-canonical NF- $\kappa \mathrm{B}$ signaling, which appears to be intensified during TNF long-term incubation, $^{20,62}$ to the canonical pathway. In addition, GSK3 can positively affect the transcriptional activity of further transcription factors such as $\mathrm{C} / \mathrm{EBP} \beta .^{63}$ These results and others ${ }^{26}$ suggest that $\mathrm{C} / \mathrm{EPB} \beta$ is an in vivo substrate of GSK3 and that inhibition of GSK3 activity leads to C/EBP $\beta$ dephosphorylation and deactivation. Moreover, it cannot be ruled out that additional, non-transcriptional effects may play a role in this context. For instance, collapsin response mediator protein (CRMP) 2, which is a tubulin-binding protein that is phosphorylated by GSK3 at Thr509, Thr514, and Thr518, ${ }^{64}$ appears to play a role in the activation of microglia and macrophages and is involved in chronic inflammatory and degenerative neurological disease. $^{65}$

\section{Conclusions}

Combined with the literature, our data suggest a constitutive expression of GSK3 and an at most weak regulation of this kinase during TNF short- and long-term exposure. Furthermore, our data indicate that any pathophysiological or pharmacological condition leading to a dysregulation of the PKC/GSK3 system and increased GSK3 activity might destroy the defined cellular condition and the finely balanced network that are necessary for termination of inflammation-associated signaling, thereby preventing the resolution of inflammation.

\section{Abbreviations}

$\mathrm{Bcl}$, B cell lymphoma; C/EBP, CCAAT/enhancer binding protein; CRMP, collapsin response mediator protein; CXCL, CXC motif chemokine ligand; ECL, enhanced chemiluminescence; ELISA, enzyme-linked immunosorbent assay; GAPDH, glyceraldehyde-3-phosphate dehydrogenase; GSK, glycogen synthase kinase; IKK, IкB kinase; IL, interleukin; IкB, inhibitor of $\mathrm{NF}-\kappa \mathrm{B}$; Ken, Kenpaullone; LPS, lipopolysaccharide; MACS, magnetic cell separation; $\mathrm{NF}-\kappa \mathrm{B}$, nuclear factor $\kappa \mathrm{B}$; NFKBIA, NF- $\kappa$ B inhibitor $\alpha$; PAGE, polyacrylamide gel electrophoresis; $\mathrm{PK}$, protein kinase; Rel, v-rel reticuloendotheliosis viral oncogene homolog; SDS, sodium dodecyl sulfate; Stauro, Staurosporine; TNF, tumor necrosis factor; TNFAIP, tumor necrosis factor $\alpha$-induced protein; TNFR1, TNF receptor type 1 .

\section{Acknowledgments}

We are grateful to Cornélia La Fougère-Brand for typing and proof-reading the manuscript as well as Ines Kiralj, Hilke Siedersleben, and Martina Krautkrämer for excellent technical assistance. We would also like to thank Kyeong-Hee Lee, Nico Föger, and Konstantin Neumann for critical discussions.

\section{Author Contributions}

All authors (i) significantly contributed to the work reported (ie, to the conception, study design, execution, acquisition of data, and/or data analysis and interpretation), (ii) have drafted, written, or substantially revised/ critically reviewed the article, (iii) have agreed on the journal to which the article was submitted, (iv) have reviewed and agreed on all relevant versions of the article (including the final version), and (v) agree to take responsibility and be accountable for the contents of the article.

\section{Funding}

This work was funded by the Deutsche Gesellschaft für Klinische Chemie und Laboratoriumsmedizin (DGKL; Stiftung für Pathobiochemie und Molekulare Diagnostik; grant 2017/20 to BW, grant 2020/21 to RB, as well as grants 2017 and 2017/19 to MC) and the German Research 
Foundation (DFG; grant 391096506 to MC). LH was supported by the Hannover Biomedical Research School (HBRS) and the $\mathrm{MD} / \mathrm{PhD}$ program Molecular Medicine.

\section{Disclosure}

Dr Bastian Welz reports grants from DGKL; Stiftung für Pathobiochemie und Molekulare Diagnostik (2017/20), during the conduct of the study. Dr Rolf Bikker reports grants from DGKL; Stiftung für Pathobiochemie und Molekulare Diagnostik (2020/21), during the conduct of the study. Ms Leonie Hoffmeister reports PhD scholarship from Hannover Biomedical Research School - MD/PhD program Molecular Medicine, during the conduct of the study. Dr Martin Christmann reports grants from DGKL; Stiftung für Pathobiochemie und Molekulare Diagnostik (2017/19) and DFG (391096506), during the conduct of the study. The donor foundations had no role in the design of the study; in the conduct of the experiments; in the collection, analysis, or interpretation of the data; in the writing or revision of the manuscript; or in the decision to publish the results. The authors report no other conflicts of interest in this work.

\section{References}

1. Buckley CD, Gilroy DW, Serhan CN, Stockinger B, Tak PP. The resolution of inflammation. Nat Rev Immunol. 2013;13(1):59-66. doi: $10.1038 /$ nri3362

2. Fullerton JN, Gilroy DW. Resolution of inflammation: a new therapeutic frontier. Nat Rev Drug Discov. 2016;15:551-567.

3. Nathan C, Ding A. Nonresolving inflammation. Cell. 2010;140:871-882.

4. Elinav E, Nowarski R, Thaiss CA, Hu B, Jin C, Flavell RA. Inflammation-induced cancer: crosstalk between tumours, immune cells and microorganisms. Nat Rev Cancer. 2013;13:759-771.

5. Sugimoto MA, Sousa LP, Pinho V, Perretti M, Teixeira MM. Resolution of inflammation: what controls its onset? Front Immunol. 2016;7:160.

6. Chen Z, Bozec A, Ramming A, Schett G. Anti-inflammatory and immune-regulatory cytokines in rheumatoid arthritis. Nat Rev Rheumatol. 2019;15:9-17.

7. Soto-Heredero G, Gomez de Las Heras MM, Gabande-Rodriguez E, Oller J, Mittelbrunn M. Glycolysis - a key player in the inflammatory response. FEBS J. 2020;287:3350-3369.

8. Boada-Romero E, Martinez J, Heckmann BL, Green DR. The clearance of dead cells by efferocytosis. Nat Rev Mol Cell Biol. 2020;21:398-414.

9. Gause WC, Rothlin C, Loke P. Heterogeneity in the initiation, development and function of type 2 immunity. Nat Rev Immunol. 2020;20:603-614.

10. Huber R, Bikker R, Welz B, Christmann M, Brand K. TNF tolerance in monocytes and macrophages: characteristics and molecular mechanisms. J Immunol Res. 2017;2017:9570129. doi:10.1155/ 2017/9570129

11. Na YR, Stakenborg M, Seok SH, Matteoli G. Macrophages in intestinal inflammation and resolution: a potential therapeutic target in IBD. Nat Rev Gastroenterol Hepatol. 2019;16:531-543.
12. Kalliolias GD, Ivashkiv LB. TNF biology, pathogenic mechanisms and emerging therapeutic strategies. Nat Rev Rheumatol. 2016;12:49-62.

13. Brenner D, Blaser H, Mak TW. Regulation of tumour necrosis factor signalling: live or let die. Nat Rev Immunol. 2015;15:362-374.

14. Vereecke L, Beyaert R, van Loo G. The ubiquitin-editing enzyme A20 (TNFAIP3) is a central regulator of immunopathology. Trends Immunol. 2009;30:383-391.

15. Bikker R, Christmann M, Preuss K, et al. TNF phase III signalling in tolerant cells is tightly controlled by A20 and CYLD. Cell Signal. 2017;37:123-135.

16. Park SH, Park-Min KH, Chen J, Hu X, Ivashkiv LB. Tumor necrosis factor induces GSK3 kinase-mediated cross-tolerance to endotoxin in macrophages. Nat Immunol. 2011;12:607-615.

17. Vallabhapurapu S, Karin M. Regulation and function of NF-kappaB transcription factors in the immune system. Annu Rev Immunol. 2009;27:693-733.

18. Gunther J, Vogt N, Hampel K, et al. Identification of two forms of TNF tolerance in human monocytes: differential inhibition of NF-kappaB/AP-1- and PP1-associated signaling. $J$ Immunol. 2014;192:3143-3155.

19. Zwergal A, Quirling M, Saugel B, et al. C/EBP beta blocks p65 phosphorylation and thereby NF-kappa B-mediated transcription in TNF-tolerant cells. J Immunol. 2006;177:665-672.

20. Welz B, Bikker R, Junemann J, et al. Proteome and phosphoproteome analysis in TNF long term-exposed primary human monocytes. Int J Mol Sci. 2019;20:e1241.

21. Hoeflich KP, Luo J, Rubie EA, Tsao MS, Jin O, Woodgett JR. Requirement for glycogen synthase kinase-3beta in cell survival and NF-kappaB activation. Nature. 2000;406:86-90.

22. Cohen P, Frame S. The renaissance of GSK3. Nat Rev Mol Cell Biol. 2001;2:769-776.

23. Piazzi M, Bavelloni A, Faenza I, Blalock W. Glycogen synthase kinase (GSK)-3 and the double-strand RNA-dependent kinase, PKR: when two kinases for the common good turn bad. Biochim Biophys Acta Mol Cell Res. 2020;1867:118769.

24. Cross DA, Alessi DR, Cohen P, Andjelkovich M, Hemmings BA. Inhibition of glycogen synthase kinase-3 by insulin mediated by protein kinase B. Nature. 1995;378:785-789.

25. Harwood AJ. Regulation of GSK-3: a cellular multiprocessor. Cell. 2001;105:821-824.

26. Hoffmeister L, Diekmann M, Brand K, Huber R. GSK3: a kinase balancing promotion and resolution of inflammation. Cells. 2020;9:820.

27. Huber R, Panterodt T, Welz B, et al. C/EBPbeta-LAP*/LAP expression is mediated by RSK/eIF4B-Dependent signalling and boosted by increased protein stability in models of monocytic differentiation. PLoS One. 2015;10:e144338.

28. Haas SC, Huber R, Gutsch R, et al. ITD- and FL-induced FLT3 signal transduction leads to increased C/EBPbeta-LIP expression and LIP/LAP ratio by different signalling modules. Br J Haematol. 2010;148:777-790.

29. Cappello C, Zwergal A, Kanclerski S, et al. C/EBPbeta enhances NF-kappaB-associated signalling by reducing the level of IkappaB-alpha. Cell Signal. 2009;21:1918-1924.

30. Robertson H, Hayes JD, Sutherland C. A partnership with the proteasome; the destructive nature of GSK3. Biochem Pharmacol. 2018;147:77-92.

31. Ghosh S, Hayden MS. New regulators of NF-kappaB in inflammation. Nat Rev Immunol. 2008;8:837-848.

32. Brasier AR, Lu M, Hai T, Lu Y, Boldogh I. NF-kappa B-inducible BCL-3 expression is an autoregulatory loop controlling nuclear p50/ NF-kappa B1 residence. J Biol Chem. 2001;276:32080-32093.

33. Wilson W 3rd, Baldwin AS. Maintenance of constitutive IkappaB kinase activity by glycogen synthase kinase-3alpha/beta in pancreatic cancer. Cancer Res. 2008;68:8156-8163. 
34. Chang TP, Vancurova I. Bcl3 regulates pro-survival and pro-inflammatory gene expression in cutaneous T-cell lymphoma. Biochim Biophys Acta. 2014;1843:2620-2630.

35. Lee RE, Walker SR, Savery K, Frank DA, Gaudet S. Fold change of nuclear NF-kappaB determines TNF-induced transcription in single cells. Mol Cell. 2014;53:867-879.

36. Huang HL, Yeh WC, Lai MZ, et al. Impaired TNFalpha-induced A20 expression in E1A/Ras-transformed cells. $B r \quad J$ Cancer. 2009;101:1555-1564.

37. Harmonizome. BCL3 ENCODE and transcription factor targets. Available from: https://maayanlab.cloud/Harmonizome/gene_set/ BCL3/ENCODE+Transcription+Factor+Targets. Accessed April 15, 2020.

38. Rouillard AD, Gundersen GW, Fernandez NF, et al. The harmonizome: a collection of processed datasets gathered to serve and mine knowledge about genes and proteins. Database. 2016;2016:baw100.

39. Kaidanovich-Beilin O, Woodgett JR. GSK-3: functional insights from cell biology and animal models. Front Mol Neurosci. 2011;4:40.

40. Beurel E, Grieco SF, Jope RS. Glycogen synthase kinase-3 (GSK3): regulation, actions, and diseases. Pharmacol Ther. 2015;148:114-131.

41. Huang A, Patel S, McAlpine CS, Werstuck GH. The role of endoplasmic reticulum stress-glycogen synthase kinase-3 signaling in atherogenesis. Int J Mol Sci. 2018;19:1607.

42. Cormier KW, Woodgett JR. Recent advances in understanding the cellular roles of GSK-3. F1000Res. 2017;6:167.

43. Tullai JW, Graham JR, Cooper GM. A GSK-3-mediated transcriptional network maintains repression of immediate early genes in quiescent cells. Cell Cycle. 2011;10:3072-3077.

44. Graham JR, Tullai JW, Cooper GM. GSK-3 represses growth factor-inducible genes by inhibiting NF-kappaB in quiescent cells. J Biol Chem. 2010;285:4472-4480.

45. Johnson A. TNF-induced activation of pulmonary microvessel endothelial cells: a role for GSK3beta. Am J Physiol Lung Cell Mol Physiol. 2009;296:L700-709.

46. Yoon K, Jung EJ, Lee SR, Kim J, Choi Y, Lee SY. TRAF6 deficiency promotes TNF-induced cell death through inactivation of GSK3beta. Cell Death Differ. 2008;15:730-738.

47. Oguma K, Oshima H, Aoki M, et al. Activated macrophages promote Wnt signalling through tumour necrosis factor-alpha in gastric tumour cells. EMBO J. 2008;27:1671-1681.

48. Mackay HJ, Twelves CJ. Targeting the protein kinase C family: are we there yet? Nat Rev Cancer. 2007;7:554-562.

49. Lei S, Su W, Liu H, et al. Nitroglycerine-induced nitrate tolerance compromises propofol protection of the endothelial cells against TNF-alpha: the role of PKC-beta2 and NADPH oxidase. Oxid Med Cell Longev. 2013;2013:678484.

50. Rosenzweig T, Braiman L, Bak A, Alt A, Kuroki T, Sampson SR. Differential effects of tumor necrosis factor-alpha on protein kinase $\mathrm{C}$ isoforms alpha and delta mediate inhibition of insulin receptor signaling. Diabetes. 2002; 51:1921-1930.
51. Schutze S, Nottrott S, Pfizenmaier K, Kronke M. Tumor necrosis factor signal transduction. Cell-type-specific activation and translocation of protein kinase C. J Immunol. 1990;144:2604-2608.

52. Muller N, Schneider B, Pfizenmaier K, Wajant H. Superior serum half life of albumin tagged TNF ligands. Biochem Biophys Res Commun. 2010;396:793-799.

53. Omura S, Asami Y, Crump A. Staurosporine: new lease of life for parent compound of today's novel and highly successful anti-cancer drugs. J Antibiot. 2018;71:688-701.

54. Mochly-Rosen D, Das K, Grimes KV. Protein kinase C, an elusive therapeutic target? Nat Rev Drug Discov. 2012;11:937-957.

55. Mattmann ME, Stoops SL, Lindsley CW. Inhibition of Akt with small molecules and biologics: historical perspective and current status of the patent landscape. Expert Opin Ther Pat. 2011;21:1309-1338.

56. Diaz-Velasquez CE, Castro-Munozledo F, Kuri-Harcuch W. Staurosporine rapidly commits 3T3-F442A cells to the formation of adipocytes by activation of GSK-3beta and mobilization of calcium. $J$ Cell Biochem. 2008;105:147-157.

57. Hornstein T, Lehmann S, Philipp D, et al. Staurosporine resistance in inflammatory neutrophils is associated with the inhibition of caspaseand proteasome-mediated Mcl-1 degradation. J Leukoc Biol. 2016;99:163-174.

58. Steinbrecher KA, Wilson W 3rd, Cogswell PC, Baldwin AS. Glycogen synthase kinase 3beta functions to specify gene-specific, NF-kappaB-dependent transcription. Mol Cell Biol. 2005;25:8444-8455.

59. Wessells J, Baer M, Young HA, et al. BCL-3 and NF-kappaB p50 attenuate lipopolysaccharide-induced inflammatory responses in macrophages. J Biol Chem. 2004;279:49995-50003.

60. Mosser DM, Zhang X. Interleukin-10: new perspectives on an old cytokine. Immunol Rev. 2008;226:205-218.

61. Carmody RJ, Ruan Q, Palmer S, Hilliard B, Chen YH. Negative regulation of toll-like receptor signaling by NF-kappaB p50 ubiquitination blockade. Science. 2007;317:675-678.

62. Mbongue JC, Nicholas DA, Torrez TW, Kim NS, Firek AF, Langridge WH. The role of indoleamine 2, 3-dioxygenase in immune suppression and autoimmunity. Vaccines. 2015;3:703-729.

63. Park BH, Qiang L, Farmer SR. Phosphorylation of C/EBPbeta at a consensus extracellular signal-regulated kinase/glycogen synthase kinase 3 site is required for the induction of adiponectin gene expression during the differentiation of mouse fibroblasts into adipocytes. Mol Cell Biol. 2004;24:8671-8680.

64. Moutal A, White KA, Chefdeville A, et al. Dysregulation of CRMP2 post-translational modifications drive its pathological functions. Mol Neurobiol. 2019;56:6736-6755.

65. Khanna R, Moutal A, Perez-Miller S, Chefdeville A, Boinon L, Patek M. Druggability of CRMP2 for neurodegenerative diseases. ACS Chem Neurosci. 2020;11:2492-2505.
Journal of Inflammation Research

\section{Publish your work in this journal}

The Journal of Inflammation Research is an international, peerreviewed open-access journal that welcomes laboratory and clinical findings on the molecular basis, cell biology and pharmacology of inflammation including original research, reviews, symposium reports, hypothesis formation and commentaries on: acute/chronic inflammation; mediators of inflammation; cellular processes; molecular mechanisms; pharmacology and novel anti-inflammatory drugs; clinical conditions involving inflammation. The manuscript management system is completely online and includes a very quick and fair peerreview system. Visit http://www.dovepress.com/testimonials.php to read real quotes from published authors. 